\title{
Optimasi Persediaan Kabel Cu Menggunakan Metode Part Period Balancing Dan Algorithm Wagner-Within
}

\author{
D. S. S. Kusuma
}

\begin{abstract}
Abstrak - Tujuan dilakukannya penelitian ini adalah untuk mengidentifikasi persediaan bahan baku berdasarkan penerapan MRP, yaitu dengan menggunakan algorithm wagner-within dan part period balancing. Permasalahan yang terjadi pada PT XYZ mengenai berlebihnya persediaan bahan baku yang tidak disesuaikan dengan permintaan produk kabel tembaga, dan pemesanan lot yang tidak dijadwalkan secara baik oleh PT XYZ. Penerapan MRP dibuat untuk menentukan ukuran pemesanan (lot) berdasarkan algorithm wagner-within dan part period balancing, dapat diketahui pemesanan yang sesuai tanpa harus terjadi penumpukan bahan baku maupun kurangnya bahan baku, selanjutnya menggunakan algorithm wagnerwithin dan part period balancing untuk diterapkan pada PT XYZ. Pada penelitian ini menggunakan algorithm wagner-within menghasilkan biaya yang dikeluarkan untuk persediaan sebesar $\mathrm{Rp} 18.313 .034$ dan part period balancing sebesar $\mathrm{Rp}$ 26.966.677. Maka dari itu, menggunakan algorithm wagner-within terbilang cukup lebih optimal dibandingkan part period balancing dalam biaya yang akan dikeluarkan, dengan selisih $\mathrm{Rp}$ 8.653.642. untuk meminimalkan biaya simpan dan pemesanaan bahan baku dan persediaan bahan baku tembaga, stell tape, dan stell ware.
\end{abstract}

Kata Kunci-algorithm wagner-within,part period balancing.

Abstract - The purpose of this research is to identify raw material inventory based on the application of MRP, using wagner-within algorithm and part period balancing. The problems that occur at PT XYZ regarding the excess inventory of raw materials that are not adjusted to the demand for copper cable products, andorders lot that are not well scheduled by PT XYZ. The application of MRP is made to determine the order size (lot) based on the Wagner-within algorithm and part period balancing, it can be known that the order is appropriate without having to accumulate raw materials or lack of raw materials, then using the wagner-within algorithm and part period balancing to be applied to PT XYZ In this study using themethod Wagner-within algorithm produces costs incurred for inventory amounting to $R p$ 18,313,034 and part period balancing in the amount of Rp. 26,966,677. Therefore, using is wagner-within algorithm quite optimal compared to part period balancing in the costs incurred, with a difference of $R p$ 8,653,642. to minimize the cost of storing and ordering raw materials and supplies of copper, stell tape, and stell ware.

Keywords - wagner-within algorithm, part period balancing 


\section{PENDAHULUAN}

Derencanaan persediaan bahan baku bagi sebagian perusahaan adalah suatu hal yang merupakan hal yang terpenting, dimana persediaan bahan baku ini menunjang kelancaran seluruh proses produksi [1]. Dimana pertumbuhan perekonomian dan perkembangan teknologi industri terus mengalami kemajuan yang pesat dalam industri, baik maufaktur maupun bidang jasa [2]. Terlebih PT XYZ adalah perusahaan yang bergerak dalam bidang industri kabel, pada perkembangannya PT XYZ sudah memiliki banyak jenis-jenis produk, tidak hanya kabel tembaga. Dengan begitu PT XYZ, dapat dikatakan perusahaan yang semakin berkembang dari tahun ketahun, dibuktikan dengan banyaknya pemesanan kabel tembaga dan pemenuhan dari permintaan tersebut $[3,4]$. Oleh karena itu demi kelancaran jalannya suatu produksi, perusahaan harus mengelola ketersediaan bahan baku supaya tidak berlebih, hal tersebut perlu dilakukan untuk meminimalkan penyimpanan gudang bahan baku dan memnimalkan biaya pemesanan yang dikeluarkan. Secara umum perencanaan dan pengendalian produksi dapat diartikan sebagai aktivitas merencanakan serta mengendalikan material masuk dalam sistem produksi (baik bahan baku maupun bahan pembantu) mengalir dalam sistem produksi (mejadi komponen subassembly), dan keluar dari sistem produksi (berupa produk jadi atau spare part) sehingga permintaan dapat dipenuhi dengan efektif dan efisien (tepat jumlah, tepat waktu penyerahan dan biaya produksi yang minimum),[5]. Algorithm wagner-within didasarkan atas permintaan beberapa 
periode mendatang yang sudah diestimasi sebelumnya, pembelian material yang hanya dilakukan pada awal periode, serta ongkos simpan yang hanya dibebankan pada material yang disimpan lebih dari satu periode [6]. Merupakan teknik yang digunakan pada pemesanan persediaan untuk menyeimbangkan biaya setup dan penyimpanan dengan mengubah ukuran lot sebagai gambaran kebutuhan lot pada masa yang akan datang. Sebagian periode mengalami penyeimbangan untuk periode ekonomis pada economic part period yang merupakan perbandingan biaya setup dengan biaya penyimpanan [7]. Dengan metode tersebut bertujuan untuk mengetahui pengendalian persediaan yang tepat yang dapat mengatasi permasalahan tersebut. [8].

\section{METODE DAN PROSEDUR}

Untuk mengetahui persediaan bahan baku yang sesuai permintaan, menentukan berapa kali pemesanana yang harus dilakukan, terhadap persediaan bahan baku tembaga, stell tape dan stell ware. Dengan menggunakan data-data historis dari sebuah perusahaan manufaktur pembuatan kabel, yaitu data kapasitas persediaan bahan baku, data persediaan bahan baku periode Januari sampai Desember tahun 2017, data biaya simpan per/meter dan pemesanan per/sekali pesan.

\section{HASIL DAN PEMBAHASAN}

Tahap pertama yang harus dilakukan dalam menentukan persediaan bahan baku yang berlebih dan menentukan biaya yang harus dikeluarkan PT XYZ, terhadap algorithm wagner-within dan part period balancing, yang dilakakukan melalui tahapan sebagai berikut:

1. Menghitung peramalan dari periode januari sampai desember 2017, menggunakan software WINQSB berdasarkan data permintaan aktual terhadap produksi kabel $\mathrm{CU}$, untuk melihat ketersediaan bahan baku dan pemenuhan bahan baku. PT XYZ menggunakan single moving average with trend dengan alpha 0,9 . Metode ini diambil, karena PT XYZ melakukan proses produksi berdasarkan trend dan menggunakan alpha tersebut telah dikatakan realibilitas dengan lost 5\%. Nilai MPS dilakukan dari periode januaridesember 2017, untuk mengetahui perencanaan produksi untuk kedepan yang akan dilalui oleh PT XYZ.
2. Menghitung kebutuhan bahan baku dilakukan berdasarkan formulasi yang telah dilakukan peneliti terhadap PT XYZ berdasarkan bill of materials.

Tabel 1. Formulasi Kebutuhan Bahan Baku Berdasarkan

\begin{tabular}{c|c|c|c}
\multicolumn{4}{c}{ Bill Of Materials } \\
\hline Tembaga & Stell Tape & Stell Ware & Satuan \\
\hline 26 & 23 & 26 & Meter \\
\hline
\end{tabular}

Tabel 2. kebutuhan bahan baku (meter)

\begin{tabular}{cccc}
\hline Periode & Tembaga & Stell Tape & Stell Ware \\
\hline Januari & 45 & 40 & 43 \\
Februari & 52 & 46 & 50 \\
Maret & 52 & 46 & 50 \\
April & 50 & 44 & 48 \\
Mei & 46 & 40 & 44 \\
Juni & 65 & 58 & 63 \\
Juli & 73 & 65 & 71 \\
Agustus & 80 & 70 & 77 \\
September & 87 & 77 & 83 \\
Oktober & 86 & 76 & 83 \\
November & 84 & 75 & 81 \\
Desember & 64 & 56 & 61 \\
\hline
\end{tabular}

Dari Tabel 2, dapat diketahui bahwa kebutuhan bahan baku dilakukan untuk menentukan pembuatan kabel tembaga (produksi kabel), dalam periode.

3. Biaya untuk pemesanan sebesar Rp.43,500 dan biaya simpan sebesar Rp. 250. Biaya ini sudah berdasarkan yang ditetapkan oleh PT XYZ pada tahun 2017.

4. Menghitung baiaya yang dikeluarkan oleh PT XYZ terhadap penumpukan bahan baku untuk (tembaga, stell tape dan stell ware) menggunakan algorithm wagner-within.

Menghitung pemenuhan order untuk tembaga menggunakan algorithm wagner-within. Perhitungan pemenuhan order dapat di lihat pada tabel 3 dibawah ini:

Alternatif pemenuhan order dilakukan untuk menentukan jumlah persediaan bahan bahan baku tembaga, stell tape, dan stell ware untuk menentukan bahan baku yang harus dipenuhi dalam satu kali produksi kabel tembaga. Pemenuhan order pada PT XYZ dilakukan untuk mengetahui kapasitas yang dapat disimpan di gudang bahan baku, dengan kapasitas gudang 600 meter. 
Tabel 3. Tabel Qce Tembaga (Meter) 


\begin{tabular}{|c|c|c|c|c|c|c|c|c|c|c|c|c|}
\hline Periode & 1 & 2 & 3 & 4 & 5 & 6 & 7 & 8 & 9 & 10 & 11 & 12 \\
\hline \multicolumn{13}{|c|}{ Kebutuhan Bahan Baku } \\
\hline \multirow{2}{*}{ Pemenuhan } & $\mathrm{e}=1$ & $\mathrm{e}=2$ & $\mathrm{e}=3$ & $\mathrm{e}=4$ & $\mathrm{e}=5$ & $\mathrm{e}=6$ & $\mathrm{e}=7$ & $\mathrm{e}=8$ & $\mathrm{e}=9$ & $\mathrm{e}=10$ & $\mathrm{e}=11$ & $\mathrm{e}=12$ \\
\hline & 45 & 52 & 52 & 50 & 46 & 65 & 73 & 80 & 87 & 86 & 84 & 64 \\
\hline $\mathrm{e}=1$ & 45 & 97 & 149 & 199 & 245 & 310 & 383 & 463 & 550 & & & \\
\hline $\mathrm{e}=2$ & & 52 & 104 & 154 & 200 & 265 & 338 & 418 & 505 & 591 & & \\
\hline $\mathrm{e}=3$ & & & 52 & 102 & 148 & 213 & 286 & 366 & 453 & 539 & & \\
\hline $\mathrm{e}=4$ & & & & 50 & 96 & 161 & 234 & 314 & 401 & 487 & 571 & \\
\hline $\mathrm{e}=5$ & & & & & 46 & 111 & 184 & 264 & 351 & 437 & 521 & 585 \\
\hline$e=6$ & & & & & & 65 & 138 & 218 & 305 & 391 & 475 & 539 \\
\hline$e=7$ & & & & & & & 73 & 153 & 240 & 326 & 410 & 474 \\
\hline $\mathrm{e}=8$ & & & & & & & & 80 & 167 & 253 & 337 & 401 \\
\hline $\mathrm{e}=9$ & & & & & & & & & 87 & 167 & 251 & 315 \\
\hline $\mathrm{e}=10$ & & & & & & & & & & 86 & 170 & 234 \\
\hline $\mathrm{e}=11$ & & & & & & & & & & & 84 & 148 \\
\hline $\mathrm{e}=12$ & & & & & & & & & & & & 64 \\
\hline
\end{tabular}


Pemenuhan order untuk bahan baku tembaga dilakukan untuk mengetahui berapa besar kapasitas yang akan disimpan di gudang, untuk periode 1 pemenuhan ke 10, 11 dan 12 tidak dilakukan perhitungan selanjutnya karena sudah melewati kapasitas yang dimiliki oleh PT XYZ. Begitu juga untuk periode 2 pemenuhan ke 11 dan 12 , periode 3 pemenuhan 11 dan 12 dan periode 4 pemenuhan 12. Setelah dilakukan pemenuhan order, maka langkah selanjutnya yaitu menghitung biaya yang harus dikeluarkan atas pemenuhan order yang telah ditentukan. Dapat dilihat pada Tabel 4 hasil matriks biaya untuk bahan baku tembaga.

Setelah melakukan perhitungan pemenuhan order untuk bahan baku stell tape, untuk periode 1 pemenuhan 11 dan 12 , periode 2 pemenuhan 12 dan periode 3 pemenuhan 12 tidak dilakukan perhitungan, karena melewati kapasitas yang dimiliki oleh PT XYZ. Kemudian dilakukan perhitungan matriks biaya untuk mengetahui biaya yang dikeluarkan untuk bahan baku stell tape. Dapat dilihat pada Tabel 4 hasil perhitungan matriks biaya.

Setelah melakukan perhitungan pemenuhan order untuk bahan baku stell ware, untuk periode 1 pemenuhan 10, 11 dan 12 , periode 2 pemenuhan 11 dan 12 periode 3 pemenuhan 12 dan periode 4 pemenuhan 12 tidak dilakukan perhitungan, karena melewati kapasitas yang dimiliki oleh PT XYZ. Kemudian dilakukan perhitungan matriks biaya untuk mengetahui biaya yang dikeluarkan untuk bahan baku stell tape. Dapat dilihat pada Tabel 4 hasil perhitungan matriks biaya.

Setelah melakukan pemuhan order untuk bahan baku tembaga, stell tape dan stell ware, dilakukan perhitungan matriks biaya untuk mengetahui hasil biaya yang harus dikeluarkan PT XYZ untuk pemenuhan bahan baku tembaga. Dengan rumus $\mathrm{Z}_{10}=\mathrm{c}+\mathrm{hp} \sum_{\mathrm{i}-\mathrm{e}}^{\mathrm{e}}(\mathrm{Qie}-\mathrm{Qe}),[9]$, dari hasil yang telah dilakukan, dapat dilihat hasilnya pada Tabel 4. 